Јелена М. Јосијевић Универзитет у Крагујевцу Филолошко-уметнички факултет Катедра за англистику
УДК 811.163.41’366.55

811.111 '366.55

https://doi.org/10.18485/uzdanica.2020.17.1.8

Оригинални научни рад

Примљен: 28. фебруар 2020.

Прихваћен: 1. јун 2020.

\title{
ДИНАМИЧКИ КОМПАРАТИВ У СРПСКОМ И ЕНГЛЕСКОМ ЈЕЗИКУ
}

$A \bar{u} c \bar{u} p a \kappa \bar{u}:$ Динамичким компаративом изражава се промена интензитета неке особине или својства у просторној или временској димензији (Пипер 2005: 853). Другим речима, динамички компаратив означава постепено повећање или смањење степена испољености особине изражене морфолошким компаративом. У овом раду анализирају се лексичко-синтаксичка средства реализације динамичког компаратива у српском и енглеском језику. У контрастивној анализи два језика коришћен је Енїлеско-срйски йаралелни корйус (ЕСПК) Математичког факултета Универзитета у Београду. Дати двојезични електронски корпус пружа могућност избора смера контрастивне анализе. У овом раду проверена су оба смера (C-E и E-C). Анализа ће показати да се наспрам једног модела динамичког компаратива у српском језику јављају четири граматикализована енглеска модела, од којих чак два нису добила заслужену пажњу у досадашњој граматичкој литератури.

Кључне речи: динамички компаратив, континуирана прогресивност, континуирана регресивност, српски језик, енглески језик.

\section{УВОДНА РАЗМАТРАҢА}

Динамичким компаративом изражава се промена интензитета неког својства „у различитим просторним и/или временским околностима” (Пипер 2005: 853). Он заправо означава постепено повећање или смањење степена испољености особине која је изражена морфолошким компаративом. У литератури се још назива и компаративом континуиране прогресивности (раст особине) или регресивности (опадање особине) (Пипер 2005: 853). У граматичкој литератури два језика помињу се језичке форме којима се изражава прогресивни пораст или смањење интензитета особине или својства израженог компаративом придева. Међутим, нема контрастивних анализа овог типа компаративне конструкције у српском и енглеском језику. 
Због тога се у овом раду анализирају лексичко-синтаксичка средства реализације динамичког компаратива у два језика. У контрастивној анализи коришћен је Енїлеско-срйски йаралелни корйус (ЕСПК) Математичког факултета Универзитета у Београду. Изабрани двојезични електронски корпус пружа могућост избора смера: са српског на енглески језик $(\mathrm{C}-\mathrm{E})$ и са енглеског на српски језик $(\mathrm{E}-\mathrm{C})$. У овој контрастивној анализи одлучили смо се да анализу спроведемо у оба смера. Тиме смо желели да избегнемо могућност да, вођени актуелним граматичким описима, останемо усредсређени само на структуре које су у литератури већ описане, а да тиме и анализу лишимо могућности да укаже на форме које у досадашњим нормативним граматикама и приручницима нису описане.

Након што су изоловане и дефинисане структуре динамичких компаратива у два језика, проверена је и њихова употреба у једнојезичним електронским корпусима два језика. Као једнојезични корпус српског језика коришћен је Корйус савременоі срйской језика (КССЈ 2013) Математичког факултета Универзитета у Београду. У корпусној анализи енглеског језика коришћен је Corpus of Contemporary American English (COCA).

Осим што ће резултати ове анализе обогатити корпус контрастивних анализа енглеског и српског језика, рад ће указати и на постојање две лексичко-синтаксичке форме изражавања динамичког компаратива у енглеском језику, које до сада нису добиле заслужено место у англистичкој граматичкој литератури.

\section{ДИНАМИЧКИ КОМПАРАТИВ У СРПСКОМ ЈЕЗИКУ}

У српском језику, динамички компаратив изражава се лексичким спојем партикуле све и компаратива придева и прилога (Ковачевић 2003; Пипер 2005; Куљанин 2017). Партикула све у овој функцији јавља се уз компаратив придева:

Црно-бели све бољи из меча у меч. Под је био прекривен пикавцима и пробним цртежима за плакат, од којих је сваки био све јеgностивнији, све смелији, све силнији од претходног. Срба се осећао све уморнији. Сада је све у реду јер су резултати екипе све бољи. То значи да постајемо све бољи и све већи партнери. Из минута у минут постајали су све бољьи и конкрейнији. Збиља, ове новине постају сваким даном све gосаgније. (КССЈ 2013)

Облици компаратива придева и прилога у структурама динамичког компаратива неретко бивају и удвојени:

Позиција суверене државе биће све боља и боља. Људи живе све торе и їоре. Ћелија је „расла”, бивала све лейша и лейша, права лепотица. Изгледи за њеног 
рођака постајали су све іори и іори. Што јој се ближио било му је све лошије и лошије. Што је јесења сезона одмицала ми смо играли све боље и боље. Та идеја о позоришном комаду постаје све іора и іора, видиш. (КССЈ 2013)

Партикула све модификује значење компаративног облика уз који стоји „у смислу континуираног појачавања или смањења количине интензитета, квантитета садржаја датог придева” (Куљанин 2017: 78). Она функционише као прагматичка јединица, јер има експресиван карактер - њоме говорник изражава и субјективну оцену (Куљанин 2017: 78).

Лексичким спојем партикуле све и компаратива може се изразити стално нарастање или појачавање својства и тада говоримо о комйарайиву

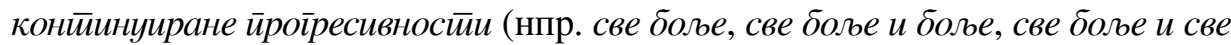
боље). Када се њоме изражава стално опадање или слабљење особине или својства, динамички компаратив назива се још и комйарайивом конииинуиране реіресивностии (нпр. све мане, све мане и мане, све мане и све мане) (Пипер 2005: 854):

Богати постају све богатији и малобројнији, али и све мање слобоgни и безбеgни, све мање срећни. Владе ће све мање и мање имати контролу над протоком информација, технологијом, болестима, мигрантима, оружјем и финансијама. Он је потом истакао да је Нови Сад од 1994. године сваке године добијао све мање и мање средстава за свој развој из републичке касе. [...] јер је боравак у јужној српској покрајини, у присуству Кфора и УНМИК-а, све мање безбеgан због нараслих криминалних активности сваке врсте. Истовремено, учешће аграрног буџета у буџету Републике Србије од самог оснивања бивало је све мање и мање. (КССЈ 2013)

Партикула све „ближе одређује реч уз коју стоји, модификује је, спецификује или градира”, па у реченици може мењати место само заједно са реченичним конституентом који модификује (Мразовић, Вукадиновић 1990: 415):

Црно-бели све бољи из меча у меч. (КССЈ)

Црно-бели из меча у меч све бољи.

*Црно-бели све из меча у меч бољи.

О партикули све, па и њеним употребама уз компаратив придева, више је писала С. Ристић (2009). Ауторка је закључила да се градуитивна партикула све употребљава уз неки реченични члан (овде компаратив), „по чему се разликује од прилога који примарно врше функцију неког реченичног члана (додатка или допуне)" (Исто: 200). С. Ристић (2009: 201-203) даље истиче да је основна разлика између партикуле све и квантитативних прилога у њиховој модификаторској функцији та што партикула све спада у универзалне логичке квантификаторе, док су квантификаторски прилози прагматичке јединице. Даље, за партикулу све ауторка констатује и да представља фокалску 
јединицу, јер на речи са којима се јавља у лексичком споју „преноси логички акценат” и тиме „организује реченични фокус” (Исто: 203).

Осим лексичког споја партикуле све и компаратива придева (који може бити и удвојен), у србистичкој литератури не помињу се друга лексичко-синтаксичка или пак чисто структурална језичка средства којима ои се изразила динамичка компаративност.

\section{ДИНАМИЧКИ КОМПАРАТИВ У ЕНГЛЕСКОМ ЈЕЗИКУ}

Компаративне конструкције у обимној граматичкој литератури енглеског језика најчешће се обрађују кроз описе основних морфолошких облика синтетичког и аналитичког компаратива (Свон 1980: 428; Квирк и др. 1985: 316; Ашер 1994: 5103; Фаулер 1996: 157; Бајбер и др. 1999: 188; Лич, Свартвик 2002: 274; Иствуд 2002: 196; Картер, МекКарти 2006: 347). Све граматике помињу групе придева код којих је нужна употреба синтетичких облика компаратива, али и оне код којих је могућа или пак нужна употреба аналитичке форме (прилог тоге + позитив придева):

(1) Синтетички суперлатив: Susan is taller than Tom.

(2) Аналитички суперлатив: Susan is more intelligent than Tom.

У свим граматикама се обрађује и компаративна поредбена конструкција. Граматике и нормативни приручници неизоставно помињу да се као допуна компаративу јављају фразе (1) и клаузе (2) са than као једином доступном везничком везом:

(1) Susan is much taller than Tom.

(2) Susan is much taller than she was last year.

Знатно ређе се у литератури ${ }^{1}$ помињу и посебне форме компаративних конструкција попут тоre than + йозийив йрияева (1) или корелайивни комйаратиив (2) (Квирк и др. 1985: 467):

(1) Susan is more than tall. She is extremely tall for her age.

(2) The taller she gets, the more confident she is.

Првима се изражава степен изражености својства који је виши од онога израженог позитивом, али без експлицитног поређења степена заступљености особине или својства (нпр. tallness) код два појма ( $X$ и $Y$ ), какво је

'Више о компарацији придева и прилога у енглеском погледати у: Зендвурт, Ван Ек 1975; Квирк, Гринбаум 1976; Квирк и др. 1985; Гринбаум, Квирк 1991; Азар 1999; Иствуд 2002; Даунинг, Лок 2006; Хадлстон, Пулам 2007; Алтенберг, Ваго 2010. 
карактеристично за обичне компаративе ( $X$ is taller than $Y$ ). Другима се изражава једносмерна зависност промене интензитета једне особине или својства (нпр. confidence) од друге (нпр. height).

Овде се најчешће помињу и структуре које одговарају динамичком компаративу. Каже се да се постепено повећање и смањење степена квалитета у енглеском језику изражава удвајањем облика компаратива (нпр. faster and faster, better and better) (Квирк и др. 1985: 467; Иствуд 2002: 285; Даунинг, Лок 2006: 487):

The scowl on his face was growing darker and darker. I think as this have and have-not gap gets wider and wider, more schools are going to drop out of the FBS. The curious machinations of an already curious Cardinals season appear to get curiouser and curiouser on Monday. I felt myself getting madder and madder. As I got closer to it, it got brighter and brighter. She gets madder and madder as he gets richer and richer. Her screams get quieter and quieter [...] fainter and fainter. (COCA)

Код перифрастичких компаратива динамичка компаративност најчешће се изражава дупликацијом прилога more (уз координативни везник and) испред позитива придева или прилога, дакле конструкцијом more and more $+\bar{u} о з и \bar{u} и в:$

We get into a financial system that gets more and more sophisticated that even the practitioners didn't understand what they were creating. We're getting these more and more powerful technologies that we can use. But as the seconds go by, it becomes more and more obvious that Benjy's not going to try to scare her. Nevertheless, the need for national standards became more and more apparent. Precisely because health care is becoming more and more complex, and therefore inherently dangerous. (COCA)

Динамичка компаративност код перифрастичких компаратива готово никада се не реализује дупликацијом читавог перифрастичког компаратива

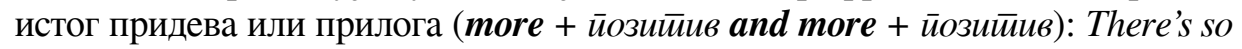
much publicity about the movies getting more expensive and more expensive (COCA).

Сви горе наведени примери илуструју компаратив континуиране прогресивности. Компаратив континуиране регресивности изражава се само перифрастички (са прилогом less):

Because you would think with more success I would have less and less embarrassing moments. National priorities, however, are becoming less and less influential as infrastructure development becomes ever more decentralized. This president has made America less and less attractive for investment and innovation. Making large building green also makes them much more expensive, so that they're less and less affordable for middle-class and working-class families. We eat, and I am feeling less and less grateful. As he tired, the strikeouts got less and less frequent. (COCA) 
Консултована граматичка литература енглеског језика не наводи више ниједну форму чије би значење одговарало динамичком компаративу. У овом раду указаћемо на постојање два засебна вида лексичких спојева са морфолошким компаративом којима се у енглеском језику изражава континуирани раст или опадање интензитета особина и својстава изражених компаративним облицима придева и прилога.

\section{КОНТРАСТИВНА АНАЛИЗА}

$$
\text { (1) } C-E
$$

Већ на основу прегледа досадашње литературе можемо закључити да,

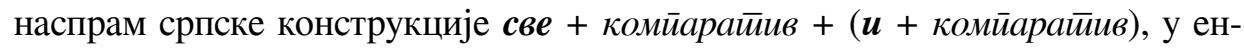

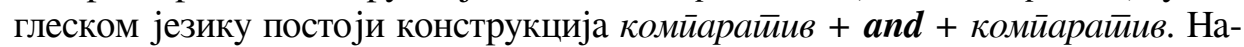
редни примери из изабраног паралелног корпуса илуструју њихову преводну еквиваленцију:

(1) Приватност је питање које постаје све значајније. Privacy is an issue that is becoming more and more important.

(2) Најпре је то био савршено лоптаст рој звезда, које су постајале све зїуснуйије ка средишту.

First there was a perfectly spherical swarm of stars, becoming more and more closely packed toward the center.

(3) Хитао је све брже и брже. He was moving faster and faster.

(4) Али сада све чешће слушам приче о једној још важнијој години. But now I am hearing more and more about an even more fateful year. (ЕСПК)

Динамичка компаративност у енглеском језику најчешће се реализује чисто структурним средствима - удвајањем форме компаратива. Међутим, наша корпусна анализа показала је да у енглеском језику постоје и лексичка средства која у споју са морфолошким компаративом имају значење континуиране прогресивности или регресивности:

(1) Једна од ствари које ме нагоне да се повлачим све gубље у осаму [...].

One of the things that drives me to withdraw ever deeper into solitude [...].

(2) Људи су све слабијеї квалитета.

People now are of ever weaker quality.

(3) И тако свет постаје све украшенији леш.

And so the world is becoming an ever more beautified corpse. 
(4) Ернест све више потпада под власт несвесног.

Ernest was falling ever more frequently under the control of the unconscious.

(5) Због тога Господ све ређе окреће лице од Земље.

This is why the Lord turns his face to the Earth ever more rarely.

(6) Неустрашиви је ношен све северније.

The Invicible was carried ever farther north. (COCA)

Примери показују да се у функцији изражавања динамичке компаративности у енглеском језику јавља и заменички временски прилог ever у лексичком споју са компаративом придева и прилога. У речнику се значење овог прилога уз компаративе дефинише као „increasingly; constantly” (OED). Прилог, дакле, компаративу додаје семантичку компоненту сталног раста интензитета:

Visionaries predicted that ever huger tube networks would emerge. As we grow ever older, The Sight grows stronger. Corporations will reverse the race to the ethical and ecological bottom by producing and marketing ever greener products. I belong to three book clubs and have an ever lengthier to read list. I shook his hand and then held it firmly, watching his eyes grow ever rounder as I spoke. They weren't forced to compare him quite so immediately with the ever taller, ever handsomer, ever more accomplished Deckie. (COCA)

Прилог ever јавља се и са дупликацијама компаратива истог придева, чиме се постиже додатни емфатички ефекат:

With customers getting ever lazier and lazier, he and his company find themselves working harder and harder. The world, an ever smaller and smaller part of it, knows him as Leonard Green. The gigantic galaxies formed when smaller proto-galaxies merged together to create ever larger and larger structure. As they spiraled their way down curving corridor, ever lower and lower, Coren sent his mind out. (COCA)

У домену динамичке компаративности, у енглеском језику конструкције са заменичким временским прилогом ever конкурентне су конструкцијама са дупликацијом облика компаратива обједињених координативним везником and. Њихову међусобну конкуретност, али и чињеницу да су као такве обе енглеске конструкције екивалентне српској све + комйарайив + $(\boldsymbol{u}+$ комйарайив), можда најбоље илуструје наредни пример:

Speaking out from edition to edition, their appetite grew, their texts became more and more aggressive and open, their allusions ever clearer $[\ldots]$.

Оглашавајући се из броја у број, њихови су апетити расли, њихови текстови постајали све айресивнији и ойворенији, њихове алузије све јасније [...]. (ЕСПК 2012) 
Иако се ever у речницима одређује као прилог, он је у овом контексту функционално партикула која испољава иста својства као и српско све. Према критеријумима које даје С. Ристић (2009), од квантификативних прилога се примарно разликује у том смислу да не врши функцију неког реченичног члана (додатка или допуне), већ се употребљава уз неки реченични члан. То је овде облик компаратива придева и прилога. Друго, и ever, налик на све, нераздвојиво је од облика компаратива и може се у реченици померати само са елементом који модификује:

Susan has been getting ever taller since the last Christmas.

* Susan has been ever getting taller since the last Christmas.

*Susan has been getting ever since the last Christmas taller.

И енглеско ever и српско све универзални су, дакле, логички квантификатори и фокалне партикуле. Конструкција ever + комйарайив заправо је у потпуности подударна српској конструкцији све + комйарайив. Конструкције се и формално и значењски пресликавају једна на другу. Међутим, овај вид динамичке компаративности у енглеском језику прилично је мање фреквентан од структуралног модела са удвајањем облика компаратива. Због тога је у потпуности оправдано и што се, упркос формалним сличностима са српским моделом све + комйарайив, енглески модел ever + комйарайив ређе јавља као његов преводни еквивалент.

Контрастивна анализа у смеру C - Е показала је и да се као енглески

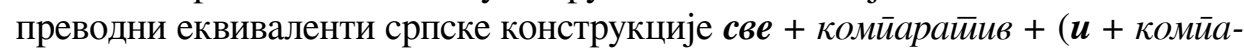
райив) јављају и лексички спојеви прилога континуираности и компаратива придева:

(1) Постаје све јасније да ће за некакве праве мере бити потребна права катастрофа.

It's becoming increasingly clear that it will take utter catastrophe to get any real policy action.

(2) Присталице су све т̈ласније.

Its supporters are increasingly more vocal.

(3) $[\ldots]$ потребу коју је тешко задовољити у свету који постаје све више мобилан, ілобалан и вирйуелан.

$[\ldots]$ a need that can be difficult to satisfy in an increasingly mobile, global and virtual world.

(4) Она је осим тога и хаотична, нестална и све више комериијализована. It is also chaotic, ephemeral and increasingly commercialized.

(5) Кумулативни захтеви постају све сиррожији од нижих нивоа ка вишим.

The cumulative demands become increasingly strict as one rises from one level to the next. (ЕСПК 2012) 
Прилози попут increasingly, progressively и growingly представљају дакле посебну групу лексичких средстава која имају семантички потенцијал да у лексичком споју са компаративом придева и прилога означе континуирани раст или опадања разлике у заступљености особине или својства. Најфреквентнији у динамичким компаративима је прилог increasingly. Прилог се дефинише као реченични адвербијал и субмодификатор са значењем „to an increasing extent; more and more" (OED). Уз компаратив придева и прилога указује на континуиран раст или опадање својства израженог компаративом, а динамичке компаративе, за разлику од партикула, твори и у лексичким спојевима са позитивима придева и прилога:

increasingly + компаратив: And the competition for available jobs will become increasingly keener. The dribble of a basketball became increasingly louder, along with the cries of sports jargon. So Mark Zuckenberg is getting increasingly richer along with the investors. The new requirements would get increasingly stricter. At the same time, increasingly greater numbers of East German tourists arrived in Hungary. They had to change to stay relevant to their little piece of the increasingly edgier pop-cultural turf. (COCA)

increasingly + позитив: It looks increasingly difficult for the president to claim this is all a hoax. Tattoos and body piercings are an increasingly popular form of self-expression. Cancer of the oropharynx has become increasingly common. Mr Johnson said he became increasingly concerned about the vulnerabilities of the nation's election infrastructure. The Cuban revolutionary model that became increasingly popular throughout the decade. (COCA)

Друго по фреквентности прилошко средство којим се компаративном својству додаје прогресивност јесте сам прилог progressively. Он се одређује као „steadily; in stages” (OED) и, налик на прилог increasingly, знатно је чешћи уз облике компаратива но уз облике позитива:

progressively + компаратив: It has grown progressively more daring in its heritage claims. It changes with every visit, becoming progressively more surreal and frightening. That comes to feel progressively more claustrophobic and frightening. The industry is getting progressively more artless. ODU's schedule gets progressively more difficult in the next few years. The girls and women are progressively more free to explore their gender expression beyond traditional femininity. (COCA)

progressively + позитив: Each addition becomes progressively difficult. She was diagnosed with Amyotrophic Lateral Sclerosis - a progressively debilitating disease, resulting in loss of all muscular control and finally death. Counterterrorism policies were built against this backdrop of encroaching web providers armed with progressively improving technologies. Pellegrini, Huberty and Jones (1995) found school children became progressively inattentive when recess was delayed. (COCA)

Трећи по фреквентности прилог који у енглеском језику учествује у реализацији динамичке компаративности јесте прилог gradually који ce дефинише као „slowly over a period of time or distance” (CD) и „in a gradual way; 
slowly; by degrees" (OED). Прилог gradually јавља се уз компаративе придева и прилога:

gradually + компаратив: You will notice that the sunlight gets gradually bluer and of course dimmer and eventually disappers. Within each subscale, examination starts with the most complex command, followed by gradually simpler commands. At my friend's suggestion, I began walking gradually longer distances on flat ground. Jim grew gradually weaker until they were free. She wonders if it gets gradually worse with age. Of course, like so many big ideas, ours seemed gradually dumber as we looked into the details. (COCA)

gradually + позитив: I became gradually aware of another sound. She was gradually able to overcome her difficulties as she got better acquainted with survivors. The gloves inside grew cold, then faintly, gradually warm. [...] and then become gradually thin at the terminal stages of anaerobic incubation. You can still enjoy a gradually improving standard of living. We should try a program of gradually increasing strengthening exercises for weak muscles. They can lie dormant for several years with gradually eroding liver health. (COCA)

Прилози progressively и gradually имају и додатно семантичко обележје. Наиме, прогресивном расту или опадању степена изражености особине додају и значењску ознаку постепености. Код лексичких спојева са позитивом придева и прилога, прилог gradually испољава и извесне специфичности. Далеко најчешће су то девербативни придеви са наставком -ing који на тој морфо-семантичкој основи и сами носе семантичку црту прогресивности:

I walked up our street, Yale Avenue, the gradually sloping hill. He began to move in random, gradually expanding patterns outside of the sprinkler's range. It was expected to be a small but gradually growing stream of refugees resettling in the United States. She sent pictures of gatherings and birthday parties with their gradually diminishing circle of friends and family - those left behind, those still alive. You can still en joy a gradually improving standard of living. We should try a program of gradually increasing strengthening exercises. (COCA)

Најмање фреквентан прилог који учествује у реализацији динамичких компаратива у енглеском језику је прилог growingly. У субмодификаторској функцији дефинише се као „іncreasingly; more and more” (OED). У изабраном корпусу није забележено ниједно његово појављивање са компаративом придева и прилога, те за сад можемо само тврдити да се јавља уз позитиве придева:

Raw Deal was more a beginning than an end to the federal effort on this growingly important issue. India will be growingly threatened by the rising economic and military strength of China. This country is growingly hostile to American blacks in different ways. The Eritrean movement recorded impressive gains against a demoralized and growingly ineffective Ethiopian army. It has what appears to be a growingly pro-American public. (COCA) 
Употребе прилога прогресивности у лексичким спојевима са компаративима придева и прилога разликују се од употреба партикуле ever. Прво, партикула ever нераздвојива је од елемента са којим је у лексичком споју. То са прилозима није случај:

It was becoming gradually faster until it reached the highest speed.

It was gradually becoming faster until it reached the highest speed.

У првом примеру прилог gradually модификује компаратив придева и прилога, док се у другом схвата као прилошка одредба за начин која као таква модификује предикат, спецификује начин на који се реализује предикација. Дакле, прилози нису фиксно везани за облике компаратива и имају своју реченичну службу, што са партикулама није случај. Међутим, оно што им је заједничко јесте да су и једни и други фокалске јединице. Енглески језик допушта начинским прилозима да се нађу и у препозицији и у постпозицији у односу на предикат. У том смислу, у првом примеру требало би да постоји извесна двосмисленост - да ли је becoming gradually или gradually faster. Таква двосмисленост овде изостаје зато што прилог ставља фокус на елемент испред кога се налази и кога ближе одређује (овде faster). Уколико прилошким средствима говорник жели да спецификује предикацију, прилог мора да се нађе испред њега, и тада као фокалска јединица на њега ставља реченични фокус.

Овим се исцрпљује опис језичких средстава која су забележена као преводни еквиваленти српске конструкције све $+\kappa o м \bar{u} а р а \bar{u} и в+(\boldsymbol{u}+\kappa o м-$

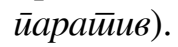

\section{(2) $C-E$}

Контрастивна анализа из смера са српског на енглески језик омогућила нам је да укажемо на појавне облике динамичког компаратива које у граматичкој литератури енглеског језика нису добиле заслужено место. Анализа је спроведена и у смеру са енглеског на српски језик како бисмо проверили да ли се као преводни еквиваленти енглеских модела динамичког компаратива можда јављају и друга лексичка средства осим партикуле све.

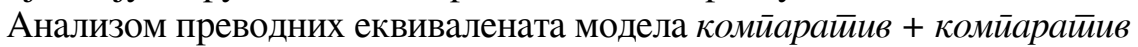

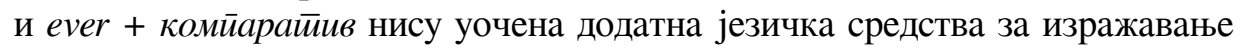
динамичке компаративности у српском језику. Као преводни еквивалент и једног и другог модела по правилу се јављала само конструкција све + ком-

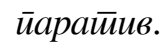


(1) So the world is becoming ever more beautified corpse.

И тако свет постаје све украшенији леш.

(2) [...] Panfarma, which recorded ever more evident sales [...].

$[\ldots]$ Панфарма која из године у годину остварује све евияенйнији раст $[\ldots]$.

(3) New and ever more proficient technologies [...].

Нове и све комйлексније технологије [...].

(4) $[\ldots]$ led by a system of cogwheels, ever more quickly turn the hands $[\ldots]$.

[...] са контролисаним системом зупчаника, све брже и брже покрећу казаљке [...].

(5) He was moving faster and faster.

Хитао је све брже и брже.

(6) The ship, moving more and more slowly now, was emerging into day. Брод који се сада кретао све сйорије и сйорије израњао је у дан.

(7) All the emotions he had felt at the time, were racing past, more and more swiftly.

Сва осећања која је искусио у то време хитала су мимо њега све брже и брже.

(8) From about 1900 onwards the aim of establishing equality was more and more openly abandoned.

Од 1900. године наовамо, циљ да се успоставе слобода и једнакост био је све ойвореније напуштен.

(9) Faster and faster spun the wheels of light.

Све брже и брже окретали су се точкови светлости. (ЕСПК 2012)

Као преводни еквиваленти енглеских конструкција йрилої йройресивно$c \bar{u} и+\kappa o м \overline{а р а \bar{и} и в ~ з а б е л е ж е н и ~ с у ~ с а м о ~ п р и м е р и ~ к о н с т р у к ц и ј е ~ с в е ~+~ к о м и ̆ а р а-~}$ $\bar{u} и в$. Међутим, у једнојезичном електронском корпусу српског језика уочен је само један пример лексичког споја прилога континуиране прогресивности и компаратива:

Задаци су постајали йроіресивно йежи, све док не би кулминирали проглашењем успешног кандидата за масона тридесет и другог ступња. (КССJ 2013)

Дакле, можемо закључити да, иако српски језик има прилоге континуираности, тј. континуиране прогресивности, попут ировресивно, консиианиино,

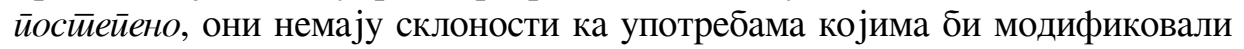
компаративно значење. То опет доводи до закључка да се као једино продуктивно језичко средство за изражавање динамичке компаративности у српском језику јавља конструкција све + комйарайив. 


\section{ЗАКЉУЧАК}

У овом раду анализирају се појавни облици динамичког компаратива у српском и енглеском језику. Србистичка литература као једино средство за изражавање динамичке компаративности наводи лексички спој партикуле све и компаратива придева или прилога који може бити и удвојен (нпр. све брже, све брже и брже). Англистичка граматичка литература као средство изражавања континуираног раста особине или својства наводи структуралне форме са удвојеним обликом компаратива (код синтетичких компаратива: faster and faster) и форме са удвојеним прилогом more и позитивом (код аналитичких компаратива: more and more swiftly).

Контрастивном анализом преводних еквивалената у смеру са српског на енглески језик установили смо да у енглеском језику постоје још два продуктивна модела за изражавања динамичке компаративности. Први модел се реализује у лексичким спојевима прилога континуираности (нпр. increasingly, gradually, progressively, growingly): He has been becoming increasingly faster. Изузетно је фреквентан и продуктиван у језичкој употреби. Други модел и формално и значењски највише наликује српском моделу јер се јавља у лексичком споју партикуле ever и компаратива придева (нпр. He has been becoming ever faster). Ипак, он је у енглеском језику мање фреквентан од друга два модела. Због тога је, упркос подударностима са српским динамичким компаративом све + комйарайив, оправдано и што се најређе бележи као његов преводни еквивалент.

Контрастивном анализом преводних еквивалената у смеру са енглеског на српски језик установили смо да се као преводни еквиваленти сва три модела динамичке компаративности у енглеском језику јавља српска конструкција све + комйарайив. Ова анализа, дакле, није успела да укаже на постојање других средстава за изражавање динамичког компаратива у српском језику. Иако српски језик поседује у свом лексичком репертоару прилошка средства која су еквивалентна енглеским прилозима континуиране прогресивности и регресивности, они за разлику од својих енглеских пандана не испољавају склоности ка употребама у којима би модификовали значење компаратива.

\section{ИЗВОРИ}

КССЈ (2013): Корӣус савремено̄̄ срӣско̄ језика, Математички факултет Универзитета у Београду. Доступно на: http://www.korpus.matf.bg.ac.rs/prezentacija/ korpus.html.

COCA (2008): M. Davies, The Corpus of Contemporary American English: 450 million words, 1900 - present. Доступно на: http://corpus.byu.edu/coca/.

ЕСПК: Енйлеско-срйски йаралелни корӣус, Математички факултет Универзитета у Београду. Доступно на: http://www.korpus.matf.bg.ac.rs/prezentacija/korpus.html. 


\section{ЛИТЕРАТУРА}

Азар (1999): Betty S. Azar, Understanding and Using English Grammar, USA: Pearson Education.

Алтенберг, Ваго (2010): Evelyn P. Altenberg, Robert M. Vago, English Grammar: Understanding the Basics, Cambridge - New York: Cambridge University Press.

Aшер (1994): Ron E. Asher, The Encyclopedia of Language and Lingusitics, Oxford: Pergamon Press.

Бајбер, Јохансон, Лич, Конрад, Финеган (1999): Douglas Biber, Stig Johansson, Geoffrey Leech, Susan Conrad, Edward Finegan, Longman Student Grammar of Spoken and Written English, Harlow: Pearson Education Limited.

Гринбаум, Квирк (1991): Sidney Greenbaum, Randolph Quirk, A Student's Grammar of the English Language, London: Longman.

Даунинг, Лок (2006): Angela Downing, Philip Locke, English Grammar: University Course, London - New York: Routledge.

Зендвурт, Ван Ек (1975): Reinard W. Zandvoort, Jan A. Van Ek, A Handbook of English Grammar, London: The English Book Society.

Иствуд (2002): John Eastwood, Oxford Guide to English Grammar, Oxford: Oxford University Press.

Јосијевић (2016): Јелена Јосијевић, Модели перифрастичког суперлатива са афирмативним универзалним квантификаторима у енглеском језику, Philologia Mediana, 8, 467-477.

Јосијевић (2019): Јелена Јосијевић, Модели афирмативне лексичко-синтаксичке суперлативности у српском и енглеском језику, у: М. Ковачевић (ур.), Вуков

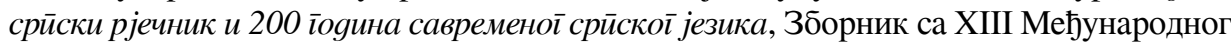

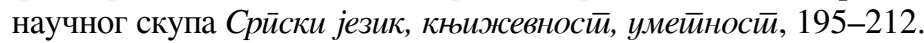

Картер, МекКарти (2006): Ronald Carter, Michael McCarthy, Cambridge grammar of English: A comprehensive guide, Cambridge: Cambridge University Press.

Квирк, Гринбаум, Лич, Свартвик (1985): Randolph Quirk, Sidney Greenbaum, Geoffrey Leech, Jan Svartvik, A Comprihensive Grammar of the English Language, London/New York: Longman.

Ковачевић (2003): Милош Ковачевић, Перифрастичка компарација у српском

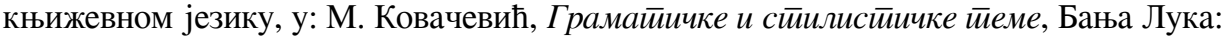
Књижевна задруга, 9-46.

Ковачевић (2009а): Милош Ковачевић, Степеновање у оквиру суперлатива, у: М. Ковачевић, Оїлеgи из срӣске синйаксе, Београд: Друштво за српски језик и књижевност, 27-39.

Ковачевић (2009б): Милош Ковачевић, Експресивне синтагме са суперлативним значењем, у: М. Ковачевић, Оїлеgи из срйске синйаксе, Београд: Друштво за српски језик и књижевност, 11-26.

Лич, Свартвик (2002): Geoffrey Leech, Jan Svartvik, A Communicative Grammar of English, New York: Routledge.

Мразовић, Вукадиновић (1990): Павица Мразовић, З. Вукадиновић, Грама-

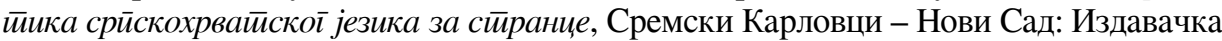
књижарница Зорана Стојановића. 
Пипер (2002): Предраг Пипер, Степеновање у граматици и речнику, Зборник Майице срйске за слависииику, 61, 59-78.

Пипер (2005): Предраг Пипер, Категоријални комплекс квалификације и квантификације, у: П. Пипер, И. Антонић, В. Ружић, С. Танасић, Љ. Поповић, Б. Тошовић, Синйакса савременої срйской језика. Просйа реченица, Београд - Нови Сад: Институт за српски језик САНУ, Београдска књига, Матица српска.

Пипер, Клајн (2013): Предраг Пипер, Иван Клајн, Нормайивна ірамайика срӣскоі језика, Нови Сад: Матица српска.

Ристић (2009): Стана Ристић, Моgификација значења и лексички моgификайори у срйском језику, Београд: Институт за српски језик. Press.

Свон (1980): Michael Swan, Practical English Usage, Oxford: Oxford University

Фаулер (1996): Henry W. Fowler, A Dictionary of Modern English Usage, Oxford: Oxford University Press.

Хадлстон, Пулам (2007): Rodney Huddleston, Geoffrey Pullam, A Student's Introduction to English Grammar, Cambridge: Cambridge University Press.

\author{
Jelena M. Josijević \\ University of Kragujevac \\ Faculty of Philology and Arts \\ English Department
}

\title{
DYNAMIC COMPARATIVES IN SERBIAN AND ENGLISH
}

Summary: Dynamic comparatives are used to express changing intensities of adjectival/adverbial scalar properties in spatial and temporal dimension (Piper 2005). In other words, dynamic comparatives are used to signify the continual increase or decrease in the intensity of any property expressed by morphological comparatives. This paper analyzes lexical and/or structural means of expressing dynamic comparatives in Serbian and English. The contrastive analysis has been conducted with electronic parallel corpus Englesko-srpski paralelni korpus (ESPK) which allows its users to select the desired direction. Here, we have opted for performing the analysis in both directions: from Serbian to English $(\mathrm{S}-\mathrm{E})$ and from English to Serbian $(E-S)$.

The analysis shows that dynamic comparative appears in only one form in Serbian: particle sve + comparative ( $+i+$ comparative). In English language, there are four grammaticalised models of dynamic comparative: (1) synthetic comparative + and + synthetic comparative (of the same lexeme), (2) more + and + more + positive (used with adjectives which have analytic comparison only), (3) adverbial particle with universal quantificational force ever + positive, and finally (4) adverbials like increasingly, progressively, gradually or growingly + comparative/positive.

Keywords: dynamic comparative, continual progressivity, continual regressivity, Serbian, English. 